\title{
Baksa Eszter
}

\section{A felzárkóztatási politika magyar szemszögből}

\author{
(Nagy Sándor Gyula - Heil Péter (Szerk.): A kohéziós politika elmélete \\ és gyakorlata. Európai uniós fejlesztési programok- \\ belülröl nézve. Akadémia Kiadó, Budapest, 2013, 265 oldal, 4950 Ft)
}

Hiánypótló mủvet vehet kezébe az olvasó: magyar nyelven ez idáig nem született ilyen átfogó munka az Európai Unió Magyarországnak szánt kohéziós politikájáról, a források felhasználásáról és a hazai pályázatkezelő intézményrendszer egészéről. A könyv megjelenése már csak azért is időszerű volt, mert megírásakor (a kéziratot 2013 februárjában zárták le) folytak a tárgyalások a 2014 és 2020 közötti tervezési időszak pénzügyi keretéről, valamint a tagállami és regionális finanszírozási programok előkészítéséről - ahogy ezt az előszóban Andor László, az Európai Bizottság foglalkoztatásért, szociális ügyekért és társadalmi összetartozásért felelős biztosa is hangsúlyozta -, és most vagyunk a hétéves tervezési időszak első évében.

Bár a kötetet szerkesztőként Nagy Sándor Gyula és Heil Péter jegyzi, a könyv sokszerzős: a két szerkesztőn túl Ambrovics Andrea, Berky Tamás, Borbás Gabriella, Kullmann Ádám és Lóránd Balázs is dolgozott rajta.

Az I. fejezet Kohéziós politika az Európai Unióban címmel történeti áttekintést ad, a programozási időszakokra bontva. A kohéziós politikák során használt fogalmak (például szubszidiaritás, programozás, partnerség, társfinanszírozás, addicionalitás, esélyegyenlőség, fenntartható fejlődés, monitoring és értékelés, fenntarthatóság, abszorpciós kapacitás) tisztázása és a nemzetközi összefoglaló után a magyar felzárkóztatási politikát veszi górcső alá, a csatlakozás előtti állapotoktól mostanáig, az intézményrendszer kialakulásán és folyamatos változásán keresztül mutatva be a fejlesztéspolitika hazai megvalósulását.

A II. fejezet - Stratégia, programok és projektfejlesztés - a kohéziós politika céljaival indít, majd bemutatja a tervezés folyamatát, a fejlesztési dokumentumokat. A hazai intézményrendszert is ez a rész taglalja, remek nemzetközi összehasonlításokkal az Irányító Hatóságok helyére és hatáskörére, a szaktárcákhoz való viszonyra vonatkozóan. Itt olvashatunk alapos elemzést a közremüködő szervezetekről is, a fejezet mellékletében pedig a teljesítményalapú finanszírozási rendszer leírását találjuk. Ugyancsak megismerhetjük a hazai gyakorlat projektkiválasztási módszereit és a végbement átalakulásokat, valamint 
a projektfejlesztés, pályázatkészítés alapelveit. Bár a bevezetőben a szerkesztők azt írják, hogy a könyv „gyakorlatiasabb, és a minimálisan szükséges elméleti háttér megadásán túl a felzárkóztatási politika tényleges megvalósulását igyekszik elemezni”, ebben a részben a gyakorlati bemutatás mégis hiányos, inkább az elméleti háttérre és a szakirodalomra fókuszálnak.

A III. fejezetet Nemzetközi tapasztalatok címmel teljes egészében Berky Tamás írta, szemügyre véve más tagállamok kohéziós politikai támogatását, a források felhasználását fejlesztési területenként. Ez a rész a nemzeti stratégiai dokumentumokat és operatív programokat hasonlítja össze. Elemzi a kohéziós politika intézményrendszerét, a különböző intézmények feladatait és hatásköreit az egyes tagállamokban. Rövid kitekintést ad az EU-n kívüli fejlesztéspolitikákról, kiemelve az Egyesült Államok és Kína gyakorlatát.

A IV. fejezetben (Értékelés) Lóránd Balázs vezeti be az olvasót az uniós értékelési módszertanba, elemezve az ehhez kiadott szakirodalmat, és bemutatva a használt eszközöket és technikákat. Lóránd leginkább az 1990-es években kiadott szakirodalomra támaszkodik, így a kohéziós politikáról szóló értékelésekét még a -2004es bővítés előtti időszakra vonatkozóan ismerhetjük meg. Rámutat az értékelés hasznára is. Az egyes szerzőket csoportokba sorolja, amiből megtudható az is, hogy a felzárkóztatási politikát ki és miért tartja sikeresnek vagy éppen sikertelennek. Ez a másik olyan fejezet, ahol a szerző szinte kizárólag az elméleti háttér bemutatására összpontosít. Az olvasónak a könyv címében szereplő „gyakorlat” szóról azonban helyenként más juthat eszébe (például: hol találom a pályázati kiírásokat, mire tudok pályázni és így tovább).

$\mathrm{Az}$ V. és egyben utolsó fejezetben Szakpolitikai tapasztalatok - jó és rossz példák címmel a szerzők a felzárkóztatási pénzeknek az egyes szektorokra gyakorolt hatását elemzik, a magyar és a nemzetközi tapasztalatok szintjén egyaránt. A kis- és közévállalkozói szektor, a humán és infrastruktúra-fejlesztések, a regionális és önkormányzati fejlesztések, az intézményi kapacitásfejlesztés és a közigazgatás modernizációja mind a vizsgálódásuk fókuszába került, ahol számos hazai és más tagállamokból vett példával illusztrálják a felzárkóztató politikai hatásait.

A könyv széles nemzetközi szakirodalmat dolgoz fel, hasznos információkat nyújtva nemcsak a szakmabeliek, hanem az érdeklődő laikus olvasók számára is. A megértést segíti a kötet elején található rövidítések jegyzéke, valamint a fejezetekben található számos saját szerkesztésủ táblázat és ábra. Kritikaként mindenképpen meg kell említeni, hogy az egyes fejezetek nyelvezete nem homogén: néhol kötetlenebb a stílus, máshol szigorúan szakmai. Emellett, amennyiben újabb kiadást terveznek, javaslom, hogy tüntessék fel a szerzők nevét az egyes fejezeteknél, a tartalomjegyzékben és esetleg a fejlécben is, ne csak az impresszumban. Érdemes lenne pár soros életrajzot is közölni a szerzőkről a kötet végén, hogy az olvasó kutatási területüket és munkásságukat is megismerhesse. 